\title{
RENAL HANDLING OF WATER, UREA AND ELECTROLYTES IN WILD SOUTH AMERICA FUR SEAL (ARCTOCEPHALUS AUSTRALIS)
}

\author{
Alfredo E. Le Bas ${ }^{1}$
}

\begin{abstract}
Fur seals alternate foraging at sea and fasting periods ashore. During fasting, energy and water are supplied by fat stores, but little is known about the transition from feeding to fasting metabolism. To evaluate the variation on land of significant parameters of urea and hydromineral metabolism, urine $\mathrm{pH}$, plasma and urine osmolality, creatinine, urea, $\mathrm{Na}^{+}, \mathrm{K}^{+}, \mathrm{Cl}^{-}$an $\mathrm{Ca}^{2+}$ were determined in 65 wild South American fur seals (Arctocephalus australis) from Lobos Island, Uruguay. Urine/ plasma ratio $(\mathrm{U}: \mathrm{P})$ and fractional excretion (FE) were calculated for creatinine, urea, $\mathrm{Na}^{+}, \mathrm{K}^{+}, \mathrm{Cl}^{-}$and $\mathrm{Ca}^{2+}$. As no significant differences were found between categories (immature, pregnant and non lactating, pregnant and lactating females, and immature males), pooled data allowed to perform correlation and regression tests. Correlated variables allow to characterize a post-absorptive (high FE of urea, urine urea and osmolality, associated with low U:P quotient for creatinine and urea) as well as fasting condition (low FE of urea, urine urea and osmolality, associated with high U:P quotient for creatinine and urea). The FE of urea versus log creatinine U:P plot suggests active urea secretion at low urine flows. Comparative urine analysis is consistent with a possible event of seawater ingestion in a young male: highest urine $\mathrm{Na}^{+}\left(336 \mathrm{mmol}^{-1}\right)$ and $\mathrm{Cl}^{-}\left(265.74 \mathrm{mmol}^{-1}\right)$ concentrations associated with low urine urea concentration $\left(657.24 \mathrm{mmol}^{1-l^{-1}}\right)$.
\end{abstract}

Resumen - Los lobos marinos alternan períodos de forrajeo en el mar con ayuno en tierra. Durante el ayuno, energía y agua son provistos por las reservas grasas, pero poco se conoce sobre la transición del metabolismo de alimentación al de ayuno. Para evaluar la variación en tierra de parámetros relacionados al metabolismo hidromineral y de la urea, se determinó el pH urinario, así como los títulos plasmáticos y urinarios de osmolalidad, creatinina, urea, $\mathrm{Na}^{+}, \mathrm{K}^{+}, \mathrm{Cl}^{-}$y $\mathrm{Ca}^{2+}$ a partir de 65 ejemplares de lobo fino sudamericano (Arctocephalus australis) en Isla de Lobos, Uruguay. El cociente orina/plasma (U:P) y la tasa de excreción (FE) fueron calculados para creatinina, urea, $\mathrm{Na}^{+}, \mathrm{K}^{+}, \mathrm{Cl}^{-}$y Ca ${ }^{2+}$. No encontrándose diferencias significativas entre categorías (hembras inmaduras, preñadas no lactíferas, preñadas lactíferas y machos inmaduros), el pool de datos permitió realizar tests de correlación y regresión. Las variables correlacionadas permiten caracterizar estados post-absortivos (altas FE de urea, urea urinaria y osmolalidad, asociadas con bajos cocientes U:P de creatinina y urea) así como estados de ayuno (bajas FE de urea, urea urinaria y osmolalidad, asociadas con altos cocientes U:P de creatinina y urea). La relación entre la FE de urea y el log del cociente U:P de creatinina sugiere secreción activa de urea asociada a débitos urinarios bajos. El análisis comparativo de orina es consistente con un posible caso de ingestión de agua de mar por parte de un macho joven: las mayores concentraciones de $\mathrm{Na}^{+}\left(336 \mathrm{mmol.l}^{-1}\right)$ y Cl $\left(265.74 \mathrm{mmol}^{-1} \mathrm{l}^{-1}\right)$, asociadas con bajo nivel de urea urinaria $\left(657.24 \mathrm{mmol} . \mathrm{l}^{-1}\right)$.

Keywords: Arctocephalus australis, fur seal, pinniped, blood, urea.

\section{Introduction}

Among pinnipeds, fur seals (Arctocephalini) exhibit a particular pattern of alimentation between continuous foraging at sea and fasting periods ashore. This pattern is expressed in females nursing pups, and leads to a highly predictable alternation of periods of high food intake associated with periods ashore. On land, water balance is complicated by simultaneous thermoregulatory problems, water export in milk provided to the pup, and the need to excrete products of catabolism in the urine.

Important metabolic changes accompany foraging in pinnipeds (Smith, 1936; Schmidt-Nielsen et al., 1959). During foraging, energy is supplied by fish lipids and amino acid absorption, and a great amount of urea is eliminated by the kidneys. Hydration occurs from water present in food. During this period, animals store energy as fat. During fasting periods, energy and water are obtained from the catabolism of fat store and few urea and water are eliminated (Ortiz et al., 1978; Schweigert, 1993a). The transition from feeding to fasting is interesting from the point of view of water and urea handling. While there is still much urea to eliminate, fasting on land and thermoregulation enhance water saving, and therefore, diuresis is minimal. In this circumstance, urine water can be insufficient for urea excretion, and ingestion of small quantities of seawater could increase total urine volume, allowing urea excretion (Gentry, 1981). Although experimental work has been unable to demonstrate that pinnipeds drink sea water (Pilson, 1970; Depocas et al., 1971; Ortiz et al., 1978), several observations indicate behavior resembling sea water drinking in pinnipeds after foraging trips (Brown, 1952; Gentry, 1981; Vaz-Ferreira, Facultad de Ciencias, Montevideo, Uruguay, pers. comm.). No physiological information is available about this behavior in field conditions.

Basic aspects of kidney physiology have been studied in pinnipeds (Irving et al., 1935; Smith, 1936; Bradley and Bing, 1942; Hiatt and Hiatt, 1942; Ladd et al., 1951; Page et al., 1954; Bradley et al., 1954; Lowrance et al., 1956; Schmidt-Nielsen et al., 1959; Murdaugh et al., 1961; Pilson, 1970; Depocas et al., 1971; Tarasoff and Toews, 1972; Ortiz et al., 1978 and Davis et al., 1983). However, few papers deal with urine and plasma samplings based on many individuals in natural conditions (Bester, 1975; Schweigert, 1993a,b). In addition, some data on plasma and urine composition are available for South America fur seal (Arctocephalus australis) (Schweigert, 1993a).

\footnotetext{
${ }^{1}$ Sección Fisiología y Nutrición, Facultad de Ciencias and Departamento de Biofísica, Facultad de Medicina (Universidad de la República). Protección de Fauna Marina (PROFAUMA). Montevideo, Uruguay.

Fax: ** (598 2) 52586 17. E-mail: lebas@fcien.edu.uy.

Correspondende should be addressed to Alfredo E. Le Bas. Sección Fisiología y Nutrición. Facultad de Ciencias. Iguá 4225. Montevideo, 11400. Uruguay.
} 
The aims of the this study were 1) to assess the metabolic adaptations in this species, especially, the renal handling of water, salt and urea in the transition from feeding to fasting; and 2) to provide field data allowing to estimate physiological adjustments for fasting in natural conditions during the winter (non-breeding) season in a representative sample of South American fur seal individuals.

Abbreviations: (cr) creatinine, (FE) fractional excretion, $\left(\mathrm{FE}_{\mathrm{u}}\right)$ fractional excretion of urea, $\left(\mathrm{L}_{\mathrm{s}}\right)$ standard length, (os) osmolality, $(\mathrm{P})$ plasma, $(\mathrm{U})$ urine, $(\mathrm{u})$ urea, $\left(\mathrm{U}_{\mathrm{os}}\right)$ urine osmolality, $\left(\mathrm{U}_{\mathrm{u}}\right)$ urine urea, (U:P) urine/plasma quotient, $\left(\mathrm{U}: \mathrm{P}_{\mathrm{cr}}\right)$ urine/plasma quotient of creatinine, $\left(\mathrm{U}: \mathrm{P}_{\mathrm{Na}}\right)$ urine/plasma quotient of sodium, $\left(\mathrm{U}: \mathrm{P}_{\mathrm{u}}\right)$ urine/plasma quotient of urea.

\section{Material and methods}

\section{Animals}

South America fur seals, Arctocephalus australis Zimmermann, 1783 (Mammalia - Otariidae), occur on the coasts and offshore islands from Peru to southern Brazil (King, 1983). In Uruguay, Lobos Island ( $35^{\circ} 01^{\prime} 38^{\prime \prime}$ S, $54^{\circ}$ $\left.52^{\prime} 55^{\prime \prime} \mathrm{W}\right)$ is the most important breeding site, with a population estimated to be 160,000-180,000 individuals (Paez, 1999; Ponce de León, DINARA, Montevideo, Uruguay pers. comm.). Mature females give birth to one pup in November - December, and mate 5 - 8 days later. Pregnancy lasts nearly one year, including a period of delayed implantation. Pups are suckled ashore for an 8 - 12 months period (Vaz-Ferreira and Ponce de León, 1987). A. australis feeds on teleost fishes and, to a lesser degree, on cephalopods, cartilaginous fishes and crustaceans (Ponce de León et al., 1988). It disperses widely at sea: foraging trips of individuals extend up to 60 - 105 miles from Lobos Island in winter (Vaz-Ferreira, 1982).

\section{Sampling}

Blood and urine samples were obtained from $65 \mathrm{~A}$. australis legally shot dead by the Instituto Nacional de Pesca to evaluate pregnancy rate in August 1993 on Lobos Island. Blood samples were collected immediately after death in plastic heparinized tubes following heart incision. They were centrifuged at $1500 \mathrm{~g}$ for 15 minutes within an hour. Urine samples were obtained by puncturing the urine bladder after laparatomy. Plasma and urine samples were frozen at $-20^{\circ} \mathrm{C}$ until laboratory analyses could be conducted six months later. Data on the standard length $\left(\mathrm{L}_{\mathrm{s}}\right.$, in $\left.\mathrm{cm}\right)$ and other standard corporal measures (American Society of Mammalogists, 1967) were collected for each animal. Females were examined for pregnancy and lactation. Body mass (BM) was estimated from standard length (Ximenez et al., 1984). Age ( $t$, in years) was estimated from von Bertalanffy's model (Batallés et al., 1990):

$$
\begin{gathered}
\mathrm{BM}=1.34 \times 10^{-5}\left(\mathrm{~L}_{\mathrm{s}}\right)^{3.068}\left(\sigma^{\prime \prime}\right) \\
\mathrm{BM}=8.65 \times 10^{-5}\left(\mathrm{~L}_{\mathrm{s}}\right)^{2.684}\left({ }^{\circ}\right) \\
\mathrm{L}_{\mathrm{s}}=186.20\{1-\exp [-0.152(\mathrm{t}+3.597)]\}\left(\sigma^{\prime \prime}\right) \\
\mathrm{L}_{\mathrm{s}}=144.70\{1-\exp [-0.187(\mathrm{t}+4.178)]\}(\text { O })
\end{gathered}
$$

To evaluate if sex and sexual status may influence the concentration of the measured plasma and urine constituents (see below) animals were divided into the following categories: non-pregnant and non-lactating, pregnant and non-lactating, pregnant and lactating females and males. Sexual maturity of non-pregnant and non-lactating females and males was inferred from age and global morphometric data.

\section{Plasma and urine analyses}

Plasma or urine constituents were measured as follows: osmolality by freezing point depression (Fiske $\mathrm{OM}^{\mathrm{TM}}$ Osmometer, USA); $\mathrm{Na}^{+}, \mathrm{K}^{+}$, and $\mathrm{Cl}^{-}$by an electrolyte analyzer AVL 983-S (Switzerland); urinary $\mathrm{pH}$ was determined in the field with a $\mathrm{pH}$-meter before freezing (Orion Research Portable Meter SA 230, USA). Endogenous creatinine was measured by Jaffé method after deproteinizing the sample (Wiener Lab., Argentine). Urea concentration was determined enzymatically and free calcium was measured from its reaction with cresolphtalein-complexone (Wiener Lab. Argentine). Because of sometimes limited samples, all the analyses could not be carried out for each individual. Individual data have been published in Le Bas (1998).

Endogenous creatinine U:P quotient was used as an approximate index of renal handling of water because it was impossible to determining urine flow rate and inulinbased calculations (sacrificed animals). The validity of $\mathrm{U}: \mathrm{P}_{\mathrm{cr}}$ as an index of water conservation in pinnipeds is supported by experimental results from Phoca vitulina (Smith, 1936; Bradley et al., 1954; Page et al., 1954; SchmidtNielsen et al., 1959). The fractional excretion (FE) of each substance was determined dividing its U:P value by the U:P quotient of endogenous creatinine ( $\mathrm{cr}$ ) as a glomerular filtration indicator (Levinsky and Levy, 1973).

\section{Statistics}

For each substance, differences between categories were tested by Kruskall-Wallis non-parametric tests at $\mathrm{p} \leq 0.05$ (Siegel, 1956; Snedecor and Cochran, 1980). When no differences between categories were found data were pooled and tested for normality (Chi square test, $\mathrm{p} \geq 0.05$ ) in order to perform descriptive statistics, correlation and regression tests. All data are expressed in SI units (Bureau International des Poids et Mesures, 1977). Sigma Plot (version 4.0) and Statistica (version 5.0) were used for statistical analyses.

\section{Results}

The sample included 16 non-pregnant and non-lactating, 15 pregnant and non-lactating, 27 pregnant and lactating females, and seven males. Global morphometric data by categories indicated that males as well as non-pregnant and non-lactating females were immature (Tab.1).

As there were no significant differences between categories for the plasma and urine variables ( $p>0.05$, Kruskall-Wallis test), all specimens were pooled for descriptive statistics (Tab.2). As individuals \#4 and \#59 exhibited atypical values for some measures $\left(\mathrm{P}_{\mathrm{u}}, \mathrm{U}_{\mathrm{os}}, \mathrm{U}_{\mathrm{Na}}, \mathrm{U}_{\mathrm{Cl}}, \mathrm{U}: \mathrm{P}_{\mathrm{u}}, \mathrm{U}: \mathrm{P}_{\mathrm{Na}}, \mathrm{U}: \mathrm{P}_{\mathrm{Cl}}, \mathrm{FE}_{\mathrm{u}}\right.$ and $\mathrm{FE}_{\mathrm{Na}}$ ), they were excluded in correlation tests and discussed separately. 
Table 1. Mean data on the morphometrics of the Arctocephalus australis sampled for this study.

\begin{tabular}{|c|c|c|c|c|c|c|c|c|}
\hline \multirow[t]{4}{*}{ Category } & \multicolumn{6}{|c|}{ 우 } & \multicolumn{2}{|l|}{$\sigma$} \\
\hline & \multirow{2}{*}{\multicolumn{2}{|c|}{$\begin{array}{l}\text { non-pregnant } \\
\text { non-lactating }\end{array}$}} & \multirow{2}{*}{\multicolumn{2}{|c|}{$\begin{array}{c}\text { pregnant } \\
\text { non-lactating }\end{array}$}} & \multirow{2}{*}{\multicolumn{2}{|c|}{$\begin{array}{l}\text { pregnant } \\
\text { lactating }\end{array}$}} & \multirow[b]{3}{*}{ Mean \pm SD } & \multirow[b]{3}{*}{$\mathrm{N}$} \\
\hline & & & & & & & & \\
\hline & Mean \pm SD & $\mathrm{N}$ & Mean \pm SD & $\mathrm{N}$ & Mean \pm SD & $\mathrm{N}$ & & \\
\hline Standard lenght $(\mathrm{cm})$ & $109 \pm 11$ & 16 & $122 \pm 7$ & 15 & $124 \pm 6$ & 27 & $112 \pm 15$ & 7 \\
\hline Axillary girth (cm) & $72 \pm 7$ & 16 & $80 \pm 7$ & 15 & $80 \pm 6$ & 27 & $67 \pm 9$ & 7 \\
\hline Body weight (kg) & $26 \pm 7$ & 16 & $35 \pm 6$ & 15 & $36 \pm 5$ & 27 & $27 \pm 12$ & 7 \\
\hline $\begin{array}{l}\text { Age (years, decimal } \\
\text { notation) }\end{array}$ & $3,7 \pm 1,9$ & 16 & $6,0 \pm 2,0$ & 15 & $6,5 \pm 1,7$ & 27 & $2,6 \pm 1,5$ & 7 \\
\hline
\end{tabular}

Table 2. Global results of all plasma and urine data for the Arctocephalus australis sampled for this study. Data from individuals \# 4 and \# 59 are shown for particular discussion.

\begin{tabular}{|c|c|c|c|c|c|c|c|}
\hline & Mean & SD & Min & Max & $\mathrm{N}$ & $\# 4$ & \# 59 \\
\hline \multicolumn{8}{|c|}{ Plasma } \\
\hline Creatinine $\left(\mathrm{mmol} . \mathrm{l}^{-1}\right)$ & 0.10 & 0.03 & 0.05 & 0.19 & 59 & 0.08 & 0.07 \\
\hline Urea $\left(\right.$ mmol..$\left.^{-1}\right)$ & 11.38 & 2.39 & 7.34 & 18.95 & 59 & 8.40 & 7.50 \\
\hline Osmolality (mOsm.kg-1) & 336.19 & 13.76 & 298.00 & 368.00 & 54 & 337.00 & 334.00 \\
\hline $\mathrm{Ca}^{2+}\left(\mathrm{mmol} . \mathrm{l}^{-1}\right)$ & 2.05 & 0.56 & 1.03 & 4.09 & 31 & 2.05 & - \\
\hline $\mathrm{Na}^{+}\left(\mathrm{mmol} . \mathrm{l}^{-1}\right)$ & 148.56 & 5.52 & 127.20 & 166.60 & 59 & 152.40 & 147.90 \\
\hline $\mathrm{K}^{+}\left(\mathrm{mmol} . \mathrm{l}^{-1}\right)$ & 6.41 & 1.43 & 3.87 & 10.57 & 59 & 7.01 & 6.34 \\
\hline $\mathrm{Cl}^{-}\left(\mathrm{mmol} . \mathrm{l}^{-1}\right)$ & 118.94 & 5.16 & 103.00 & 138.10 & 58 & 121.90 & 112.80 \\
\hline \multicolumn{8}{|c|}{ Urine } \\
\hline Creatinine (mmol..$^{-1}$ ) & 21.44 & 10.14 & 2.60 & 46.32 & 47 & 13.50 & 20.97 \\
\hline Urea $\left(\right.$ mmol..$\left.^{-1}\right)$ & 1147.43 & 306.15 & 459.24 & 2102.34 & 46 & 2102.30 & 657.20 \\
\hline Osmolality $\left(\mathrm{mOsm} \cdot \mathrm{kg}^{-1}\right)$ & 1861.83 & 266.88 & 1338.00 & 2344.00 & 29 & 1761.00 & 2268.00 \\
\hline $\mathrm{pH}$ & 6.25 & 0.26 & 5.69 & 7.00 & 31 & - & 5.83 \\
\hline $\mathrm{Ca}^{2+}\left(\mathrm{mmol} . \mathrm{l}^{-1}\right)$ & 0.68 & 0.29 & 0.35 & 1.66 & 26 & 0.53 & - \\
\hline $\mathrm{Na}^{+}\left(\mathrm{mmol}^{-1}\right)$ & 41.79 & 56.06 & 3.20 & 336.00 & 37 & 11.60 & 336.00 \\
\hline $\mathrm{K}^{+}\left(\mathrm{mmol} . \mathrm{l}^{-1}\right)$ & 121.30 & 55.96 & 16.00 & 218.00 & 37 & 92.00 & 138.00 \\
\hline $\mathrm{Cl}^{-}\left(\mathrm{mmol} \cdot \mathrm{l}^{-1}\right)$ & 47.90 & 52.15 & 0.57 & 265.74 & 38 & 92.12 & 265.74 \\
\hline \multicolumn{8}{|c|}{ Calculations } \\
\hline $\mathrm{U}: \mathrm{P}$ creatinine & 250.16 & 118.59 & 25.99 & 539.26 & 41 & 177.90 & 298.90 \\
\hline U:P urea & 107.35 & 33.39 & 56.32 & 250.18 & 40 & 250.18 & 87.62 \\
\hline U:P osmolal & 5.72 & 0.80 & 3.95 & 6.93 & 23 & 5.23 & 6.79 \\
\hline $\mathrm{U}: \mathrm{PCa}^{2+}$ & 0.35 & 0.15 & 0.12 & 0.77 & 26 & 0.26 & - \\
\hline $\mathrm{U}: \mathrm{P} \mathrm{Na}^{+}$ & 0.28 & 0.40 & 0.02 & 2.27 & 32 & 0.08 & 2.27 \\
\hline $\mathrm{U}: \mathrm{P} \mathrm{K}^{+}$ & 20.70 & 12.07 & 2.50 & 50.39 & 32 & 13.12 & 21.77 \\
\hline $\mathrm{U}: \mathrm{PCl}^{-}$ & 0.45 & 0.48 & 0.01 & 2.36 & 31 & 0.76 & 2.36 \\
\hline FE urea & 0.52 & 0.31 & 0.20 & 1.41 & 40 & 1.41 & 0.29 \\
\hline $\mathrm{FE} \mathrm{Ca}^{2+}\left(\times 10^{-3}\right)$ & 1.95 & 1.58 & 0.79 & 8.27 & 26 & 1.46 & - \\
\hline $\mathrm{FE} \mathrm{Na}^{+}\left(\times 10^{-3}\right)$ & 1.20 & 1.43 & 0.12 & 7.60 & 32 & 0.43 & 7.60 \\
\hline $\mathrm{FE} \mathrm{K}^{+}\left(\mathrm{x} 10^{-3}\right)$ & 88.89 & 68.31 & 21.80 & 361.57 & 32 & 73.80 & 72.80 \\
\hline $\mathrm{FE} \mathrm{Cl}^{-}\left(\times 10^{-3}\right)$ & 3.60 & 8.01 & 0.02 & 40.00 & 31 & 4.25 & 7.88 \\
\hline
\end{tabular}


Urine osmolality $\left(\mathrm{U}_{\mathrm{os}}\right)$ was not correlated to creatinine U:P quotient $\left(\mathrm{U}: \mathrm{P}_{\mathrm{cr}}\right)$, but depended on urinary urea concentration, $\mathrm{U}_{\mathrm{u}}(\mathrm{r}=0.81)$. Both variables fit to the function $\mathrm{U}_{\mathrm{os}}=505.25+$ $1.16 \mathrm{U}_{\mathrm{u}}(\mathrm{p}<0.01, \mathrm{ANOVA})$. Plasma urea concentration $\left(\mathrm{P}_{\mathrm{u}}\right)$ was negatively correlated to $\mathrm{U}: \mathrm{P}_{\mathrm{cr}}$ ratio $(\mathrm{r}=-0.48)$ and fit to the function $\mathrm{P}_{\mathrm{u}}=13.78-\left(9.62 \times 10^{-3}\right) \mathrm{U}: \mathrm{P}_{\mathrm{cr}}(\mathrm{p}<0.01$, ANOVA $)$. The logarithm of U:P ratio for urea ( $\left.\log \mathrm{U}: \mathrm{P}_{\mathrm{u}}\right)$ was positively correlated to $\mathrm{U}: \mathrm{P}_{\mathrm{cr}}(\mathrm{r}=0.35)$ and fit to the function: $\log \mathrm{U}: \mathrm{P}_{\mathrm{u}}$ $=1.92+\left(3.17 \times 10^{-4}\right) \mathrm{U}: \mathrm{P}_{\mathrm{cr}}(\mathrm{p}<0.05$, ANOVA $)$. The logarithm of fractional excretion of urea $\left(\log \mathrm{FE}_{\mathrm{u}}\right)$ was negatively correlated to $\log \mathrm{U}: \mathrm{P}_{\mathrm{cr}}(\mathrm{r}=-0.85)$. Data fit to the function: $\log$ $\left(\mathrm{FE}_{\mathrm{u}}\right)=1.72-0.88 \log \left(\mathrm{U}: \mathrm{P}_{\mathrm{cr}}\right)(\mathrm{p}<0.01$, ANOVA) (Fig.1). Four values of $\mathrm{FE}_{\mathrm{u}}>1$ were obtained, corresponding to low $\mathrm{U}: \mathrm{P}_{\mathrm{cr}}$ values. In addition to this, the fitted curve does not reach the ordinates axis at $\mathrm{FE}_{\mathrm{u}}=1$, as in classical experiments (Chasis and Smith, 1938; Shannon, 1938).

Urinary urea-N:creatinine ratio was negatively correlated with low $\mathrm{U}: \mathrm{P}_{\mathrm{cr}}$ values, and remained constant for $\mathrm{U}: \mathrm{P}_{\mathrm{cr}}>250$ (Fig.2).

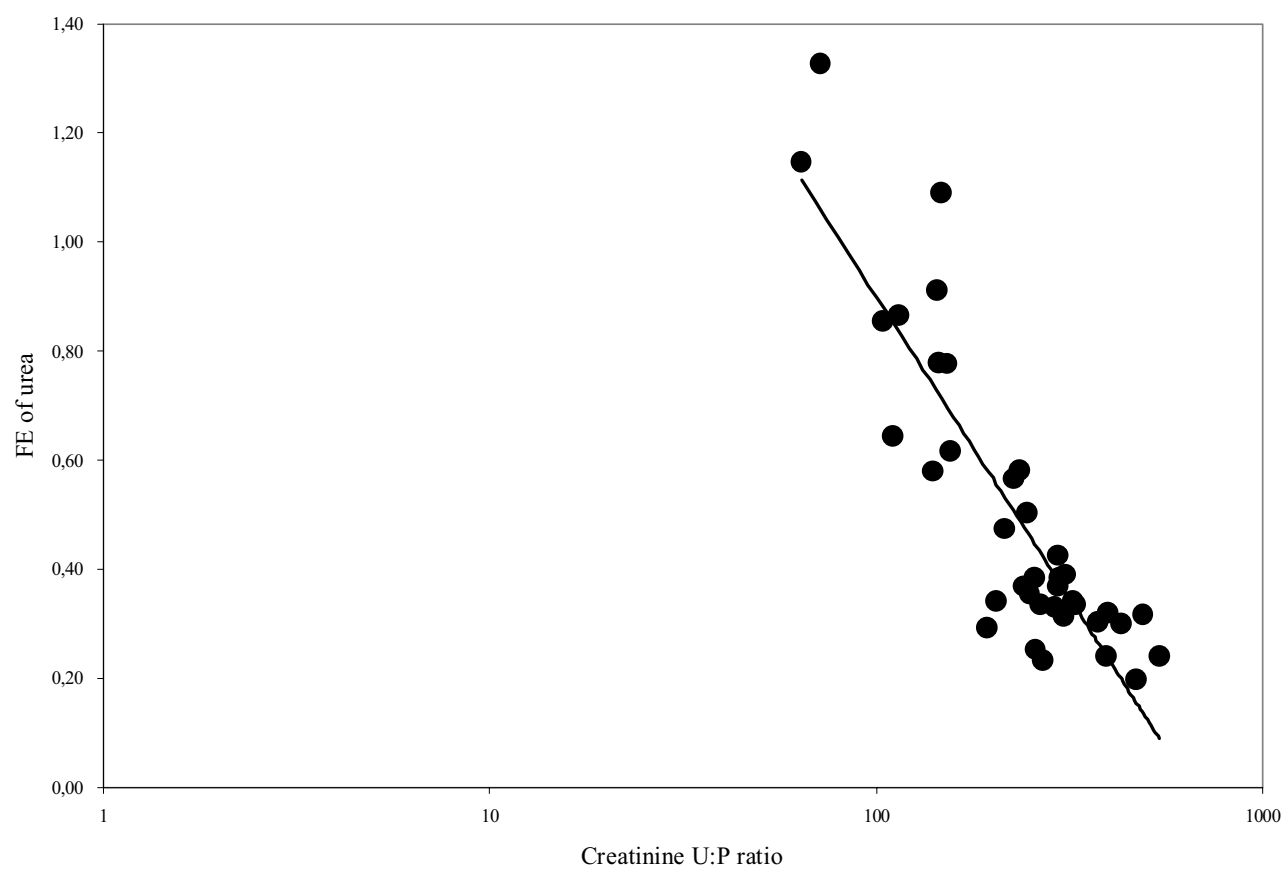

Figure 1. Plot of fractional excretion of urea $\left(\mathrm{FE}_{\mathrm{u}}\right)$ vs. creatinine urine/plasma quotient $\left(\mathrm{U}: \mathrm{P}_{\mathrm{cr}}\right)$.

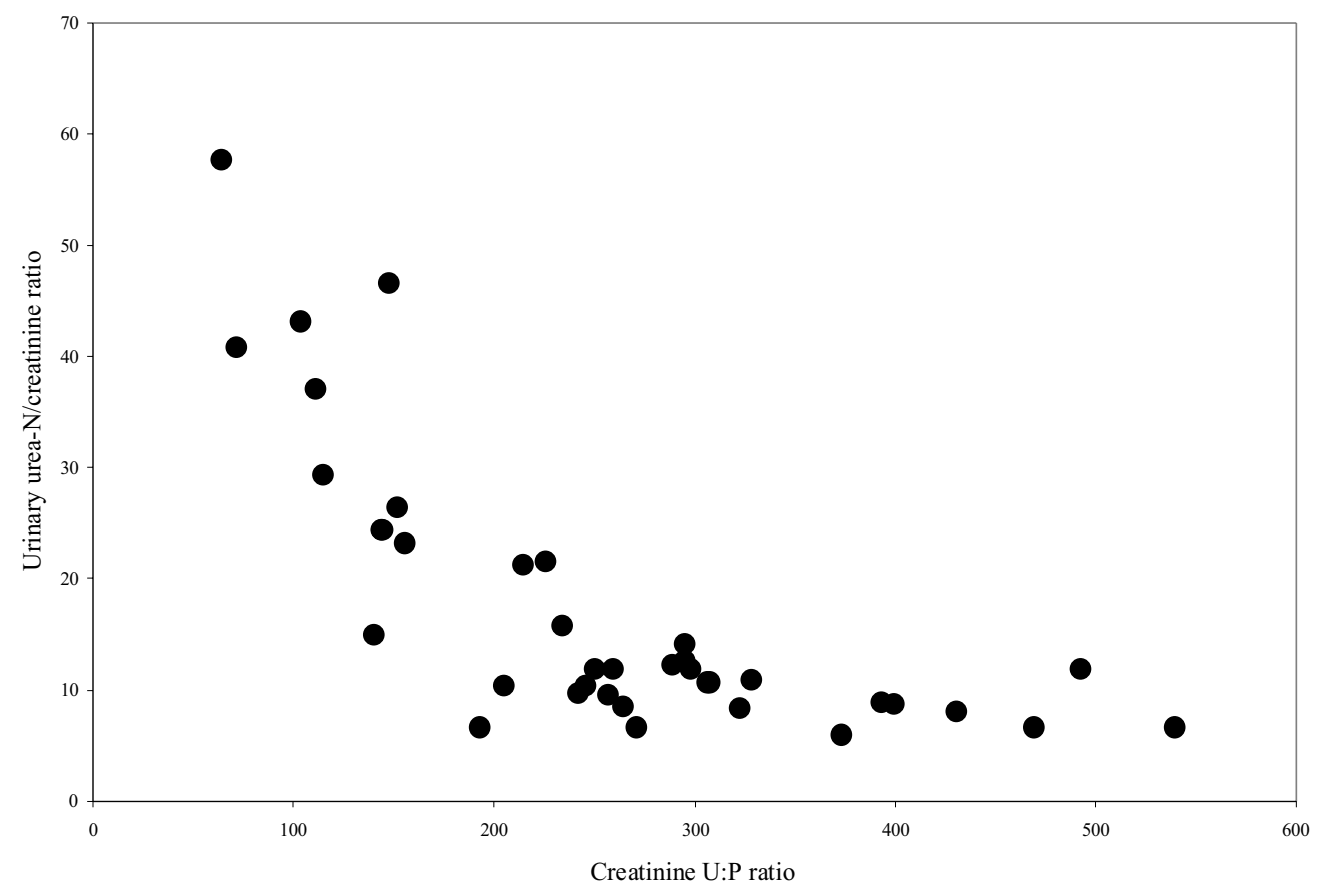

Figure 2. Plot of urinary urea-N/creatinine ratio $v s$. creatinine urine/plasma quotient $\left(\mathrm{U}: \mathrm{P}_{\mathrm{cr}}\right)$. 


\section{Discussion}

No differences in the plasma and urine variables were observed between the reproductive categories suggesting that they are not altered by sex, pregnancy or lactation at least at this stage of the annual cycle. Pooled data allowed interspecific comparisons and gave some insights on the time course of fasting metabolism on land.

\section{Urine and plasma analyses}

Plasma creatinine values in A. australis were similar to those obtained in Phoca vitulina (Smith, 1936), Callorhinus ursinus (Keyes et al., 1971) and Halichoerus grypus (Schweigert, 1993a). The $U: P_{c r}$ ratio is similar to Phoca vitulina (Bradley et al., 1954; Lowrance et al., 1956). The maximal U: $\mathrm{P}_{\mathrm{cr}}$ obtained (539.26) can be used as an approximate index of maximal water conservation at the time of this sampling. Although no data are available, higher values are presumed to occur during the breeding season (summer), when dominant males fast and support the highest temperatures without leaving territory during 1 - 11/2 months (Vaz-Ferreira, 1956). Plasma urea values were similar to Phoca vitulina (SchmidtNielsen et al., 1959), Halichoerus grypus (Greenwood et al., 1971), Arctocephalus pusillus (Bester, 1975), Zalophus californianus, Callorhinus ursinus, and Eumetopias jubatus (Wallach and Boever, 1983). Lower plasma urea values (1.32 $\times 10^{-3}$ to $\left.1.80 \times 10^{-3} \mathrm{mmol} . \mathrm{l}^{-1}\right)$ were obtained in breeding Halichoerus grypus (Schweigert, 1993a). These results were associated with extreme metabolic conditions imposed by simultaneous fasting and lactation in this species (Schweigert, 1993b). Urinary urea values in the present study have greater variance and are consistent with those obtained in Arctocephalus pusillus (Bester, 1975) and Leptonychotes weddelli (Kooyman and Drabek, 1968). Keyes et al. (1971) obtained lower values of urine urea in Callorhinus ursinus captured at sea $\left(527.50 \pm 194.36 \mathrm{mmol}^{-1} \mathrm{l}^{-1}\right)$. A positive correlation between urine urea concentration and food ingestion was demonstrated in Phoca vitulina (SchmidtNielsen et al., 1959), therefore, we can relate urine urea, and hence, the $U: P_{u}$, to metabolic status. Our $U: P_{u}$ values are similar to those obtained in Arctocephalus pusillus (Bester, 1975), but almost three times higher than values experimentally obtained in Phoca vitulina: $38.27 \pm 19.29$ mmol. $1^{-1}$ (Schmidt-Nielsen et al., 1959). The minimal and maximal urea U:P values obtained are associated to natural osmotic diuresis (post-absorbtive condition) and antidiuresis (fasting condition), respectively. Thus, this quotient and urine urea can be considered indicators of metabolic condition in pinnipeds.

The plasma $\mathrm{Na}^{+}$variance in males is greater than in other categories. The mean natremia in males is 2.2-fold greater than in other categories, consistent with data in Halichoerus grypus (Schweigert, 1993a).

As in other pinnipeds, plasma osmolality was higher than in land mammals. Urine osmolality $\left(\mathrm{U}_{\mathrm{os}}\right)$ was similar to Leptonychotes weddelli (Kooymann \& Drabek, 1968), Arctocephalus pusillus (Bester, 1975) and Halichoerus grypus (Schweigert, 1993a). Although maximal $U_{\text {os }}$ is often used as an index of urine concentrating ability in interspecific comparisons, present data reveal that $\mathrm{U}_{\mathrm{os}}$ depends on $\mathrm{U}_{\mathrm{u}}$ and not on $\mathrm{U}: \mathrm{P}_{\mathrm{cr}}$. As this quotient is proportional to water saving, its independence on $\mathrm{U}_{\text {os }}$ demonstrates that 'urine concentrating ability' is not always synonymous to 'water economy' in renal ecophysiology. On the other hand, renal adaptations to water economy in mammals are mostly known from terrestrial models (Bankir and Rouffignac, 1985).

\section{Metabolic conditions}

Although the sample was biased to females, it was achieved randomly for female categories. As the period of fasting occurs between two foraging trips, the sample corresponds to individuals caught at the mid-time of fasting, some individuals caught just after the last foraging trip or at the end of the fasting period on land. As animals fast, water loss through thermoregulation, lactation and metabolite excretion establishes water economy. Thus, enhanced water reabsorption in the kidney raises $\mathrm{U}: \mathrm{P}$ ratio of creatinine proportionally to time spent on land. As well as $\mathrm{U}: \mathrm{P}_{\mathrm{u}}, \mathrm{FE}_{\mathrm{u}}$ urinary urea-N:creatinine correlate to $\mathrm{U}: \mathrm{P}_{\mathrm{cr}}$, and this quotient is proportional to time spent on land, it is possible to infer the relative time of fasting from the study of individual urine and plasma composition. Although all sampling on land correspond to fasting animals, "postabsorbtive" (recently fed) or "fasting" (sensu stricto) conditions can be predicted for each animal. High $\mathrm{FE}_{\mathrm{u}}, \mathrm{U}_{\mathrm{u}}$ and $\mathrm{U}_{\mathrm{os}}$, associated with low $\mathrm{U}: \mathrm{P}_{\mathrm{cr}}$ and $\mathrm{U}: \mathrm{P}_{\mathrm{u}}$, indicate postalimentary condition (Smith, 1936). On the other hand, low $\mathrm{FE}_{\mathrm{u}}, \mathrm{U}_{\mathrm{u}}$ and $\mathrm{U}_{\mathrm{os}}$ associated with high $\mathrm{U}: \mathrm{P}_{\mathrm{cr}}$ and $\mathrm{U}: \mathrm{P}_{\mathrm{u}}$, suggest fasting metabolism. After some time spent on land, animals eliminate minimal quantities of urea and water. Energy gain from lipolysis and thermoregulatory water losses explain these values. Urinary ratio of urea-N:creatinine has been used as an index of the nutritional status in mammals (Parker et al., 1993; DelGiudice et al., 1995). As protein intake increases, urea-N:creatinine ratio increases. During prolonged fasting, this ratio is lower. The ratio can increase when endogenous body protein is catabolized at an accelerated rate after depletion of lipid resources. This does not appear to happen in A. australis in the present study since fasting periods in this season are usually short. As creatinine U:P ratio surpasses approximately 250, urinary urea excretion reaches a minimal plateau, suggesting the maintenance of a basal protein metabolism.

\section{Renal handling of urea}

The $\mathrm{FE}_{\mathrm{u}}$ values are higher for low $\mathrm{U}: \mathrm{P}_{\mathrm{cr}}$. As four $\mathrm{FE}_{\mathrm{u}}$ values unexpectedly exceed unity, and the regression curve can not be extrapolated to 1 for minimal $U: P_{c r}$ values, the plot suggests a methodological error, i. e. the use of endogenous creatinine. As endogenous creatinine was used for all calculations, it is difficult to compare the data presented here with similar plots based on exogenous creatinine or inuline. In several species of pinnipeds, endogenous creatinine U:P may exceed inulin U:P by 10 - $40 \%$ or more (Levinsky and Levy, 1973). On the other 
hand, creatinine:inulin clearance ratio was found to fall to values as low as 0.2 in the dog as consequence of kidney or lower urinary tract reabsorption (Ladd et al., 1956; Levinsky and Berliner, 1959). Correcting for hypothetical over and underestimation of $100 \%$ in our U:P $P_{c r}$ values, the regression curves obtained extrapolate to ordinate axis at $\mathrm{FE}_{\mathrm{u}}$ values $>1$. Recognized overestimation of creatinine U:P ratio, due to its weak proximal secretion, is minimal for high urine flows, i. e., when $U: P_{c r}$ reaches its lowest values. This makes it more likely that this methodological artifact does not affect the conclusions based on this plot. As urine debt diminution does not explain the high values of $\mathrm{FE}_{\mathrm{u}}$ obtained, it is possible that there is active urea secretion at low $U: P_{c r}$ values, i.e., when urine flow is still high. Active urea secretion has recently been described for the deepest portion of rat inner medullary duct (Kato and Sands, 1998). This sodiumdependent transport process is upregulated by water diuresis (Kato and Sands, 1999). As water restriction does not alter active urea secretion, this active transport was suggested to be physiologically important only during water diuresis (Sands, 1999). In the present study, urea and water are still abundant in the post-alimentary period. Thus, A. australis might be an interesting candidate to study active urea secretion.

Figure 2 suggests that at $U: P_{c r} \sim 250$ there is a change in the renal handling of urea. Although all animals were sampled on land and, therefore, in fasting condition, fasting metabolism (energy gain from lipid resources with minimal $\mathrm{FE}_{\mathrm{u}}$ and high $\mathrm{U}: \mathrm{P}_{\mathrm{cr}}$ ratio) is completely established from $U: P_{c r} \sim 250$, i. e., after some time of fasting on land. Maximal values of $U: P_{c r}$ are possibly associated with the imminence of a next foraging trip.

\section{Atypical animals}

Mariposia (seawater ingestion) in pinnipeds was excluded as a source of metabolic water in previous studies (Depocas et al., 1971; Tarasoff and Toews, 1972; Ortiz et al., 1978). Nevertheless, mariposia behavior was described in males of four species of pinnipeds returning from foraging trips (Gentry, 1981). In this sample, a male had the lowest $\mathrm{U}_{\mathrm{u}}\left(657.24 \mathrm{mmol} . \mathrm{l}^{-1}\right)$, the highest urine $\mathrm{Na}^{+}$ $\left(336 \mathrm{mmol}^{-1}\right)$ and $\mathrm{Cl}^{-}\left(265.74 \mathrm{mmol}^{-1}\right)$ concentrations. These values are consistent with recent seawater ingestion and the low $\mathrm{U}_{\mathrm{u}}\left(657.24 \mathrm{mmol}^{-1} \mathrm{l}^{-1}\right)$ excludes a possible ingestion of isoosmotic mollusks or crustaceans. The high $U / P_{\mathrm{Na}}$ (2.27) indicates a reduced percentage of reabsorption, consistent with a higher filtered load. As the low $U_{u}$ excludes post-alimentary condition, this finding is not consistent with the conditions suggested by Gentry (1981): a role in nitrogen excretion among fasting animals. Possibly, other factors can account for this behavior under natural conditions.

A pregnant lactating female exhibited the opposite characteristics. She presented the maximal $U_{u}$ $\left(2102.34 \mathrm{mmol}^{-1} \mathrm{I}^{-1}\right)$ as well as the maximal U:P $\mathrm{P}_{\mathrm{u}}(250.18)$. Her urine osmolality $\left(1761 \mathrm{mOsm} . \mathrm{Kg}^{-1}\right)$ was near the average values, and her U:P $P_{c r}$ was relatively low (177.92), suggesting important diuresis. The $\mathrm{U}: \mathrm{P}_{\mathrm{Na}}$ is low (0.08), indicating moderate salt intake and/or important distal interchanges, as demonstrated by the low $\mathrm{Na}^{+}: \mathrm{K}^{+}$ratio $(0.13)$ and $\mathrm{U}_{\mathrm{Cl}}\left(92.12 \mathrm{mmol}^{-1} \mathrm{l}^{-1}\right)$ values. It is possible that this animal had fed recently, and eliminated urea in a broad urinary space. Alimentary water diminishes urine osmolality below its mean value.

\section{Acknowledgements}

The author gratefully acknowledges DINARA (Dirección Nacional de Recursos Acuáticos) for assistance during sampling on Lobos Island. I would like to thank Rudy Ortiz of the Biology Department at University of California for his useful comments. I am indebted to Dr. Fritz Trillmich for editorial help, to Dr. Raúl Vaz-Ferreira for his comments on ecological aspects of this paper and to Dr. Pedro Martino for assistance with chemical analyses carried out in Montevideo Veterinary Faculty. Commercial kits for urine and plasma analyses were generously donated by Wiener Lab. This work was partially supported by the Programa de Desarrollo de las Ciencias Básicas (PEDECIBA).

\section{References}

American Society of Mammalogists (1967) Standard measurements of seals. Journal of Mammalogy 48: 459-462.

Bankir, L. and Rouffignac, C. De (1985) Urinary concentrating ability: insights from comparative anatomy. American Journal of Physiology 249 (Regulatory Integrative Comp. Physiol. 18): R643-R666.

Batallés, L.M., Pin, O. and Lima, M. (1990) [Growth study of the Southamerican Fur Seal (Arctocephalus australis), at Isla de Lobos, Uruguay] Estudio del crecimiento del lobo fino sudamericano (Arctocephalus australis) en Isla de Lobos, Uruguay. Frente Maritimo 7(A): 69-73.

Bester, M. (1975) The functional morphology of the kidney of the Cape fur seal Arctocephalus pusillus (Schreber). Madoqua Series II 4(74-80): 69-92.

Bradley, S.E. and Bing, R.J. (1942) Renal function in the harbor seal (Phoca vitulina L.) during asphyxial ischemia and pyrogenic hyperemia. Journal of Cellular and Comparative Physiology 19: 229-238.

Bradley, S.E., Mudge, G.H. and Blake, W.D. (1954) The renal excretion of sodium, potassium and water by the Harbor Seal (Phoca vitulina L): effect of apnea, sodium, potassium and water loading; pitressin; and mercurial diuresis. Journal of Cellular and Comparative Physiology 43(1): 1-22.

Brown, K.G. (1952) Observations on a newly born leopard seal. Nature 170: 982-983.

Bureau International des Poids et Mesures (1977) Le système international d'unités (SI). Third edition. Offilib Paris.

Chasis, H. and Smith, H.W. (1938) The excretion of urea in normal man and in subjects with glomerulonephritis. Journal of Clinical Investigation 17: 347-358.

Davis, R.W., Castellini, M.A., Kooyman, G.L. and Maue, R. (1983) Renal glomerular filtration rate and hepatic blood flow during voluntary diving in weddell seals. American Journal of Physiology 245 (Regulatory Integrative Comp. Physiol. 14): R743-R748.

DelGiudice, G.D., Asleson, M.A., Varner, L.W. and Hellgren, E.C. (1995) Twenty-four-hour urinary creatinine and urea 
nitrogen excretion in male white-tailed deer. Canadian Journal of Zoology 73: 493-501.

Depocas, F., Hart, J. and Fisher, H.D. (1971) Sea water drinking and water flux in starved and in fed harbor seals, Phoca vitulina. Canadian Journal of Physiology and Pharmacology 49: 53-62.

Gentry, R.L. (1981) Seawater drinking in eared seals. Comparative Biochemestry and Physiology 68A: 81-86.

Greenwood, A.G., Ridgway, S.H. and Harrison, R.J. (1971) Blood values in young gray seals. Journal of the American Veterinary Medical Association 159(5): 571-574.

Hiatt, E.P. and Hiatt, R.B. (1942) The effect of food on the glomerular filtration rate and renal blood flow in the harbor seal (Phoca vitulina L.). Journal of Cellular and Comparative Physiology 19: 221-227.

Irving, L., Fisher, K.C. and McIntosh, F.C. (1935) The water balance of a marine mammal, the seal. Journal of Cellular and Comparative Physiology 6: 387-391.

Kato, A. and Sands, J.M. (1998) Evidence for sodiumdependent active urea secretion in the deepest subsegment of the rat inner medullary collecting duct. Journal of Clinical Investigation 101: 423-428.

Kato, A. and Sands, J.M. (1999) Urea transport processes are induced in rat IMCD subsegments when urine concentrating ability is reduced. American Journal of Physiology 276: F62-F71.

Keyes, M.C., Barron, E.J. and Ross, A. (1971) Analysis of urine of the northern fur seal. Journal of the American Veterinary Medical Association 159(5): 567-570.

King, J.E. (1983) Seals of the world. Oxford University Press, Oxford.

Kooyman, G.L. and Drabek, C.M. (1968) Observations on milk, blood, and urine constituens of the weddell seal. Physiological Zoology London 41: 187-194.

Ladd, M., Liddle, L. and Gagnon, J.A. (1956) Renal excretion of inulin, creatinine and ferrocyanide at normal and reduced clearance levels in the dog. American Journal of Physiology 184: 505-514.

Ladd, M., Raisz, L.G.; Crowder, C.H. and Page, L.B. (1951) Filtration rate and water diuresis in the seal, Phoca vitulina. Journal of Cellular and Comparative Physiology 38: 157-164.

Le Bas, A. (1998) [Renal handling of water, urea and electrolytes in wild south american fur seal, Arctocephalus australis (Zimmermann, 1783) (Mammalia, Otariidae)] Manejo renal de agua, urea y electrólitos en el lobo fino sudamericano, Arctocephalus australis (Zimmermann, 1783) (Mammalia, Otariidae) MSc Thesis Programa de Desarrollo de las Ciencias Básicas (PEDECIBA) Facultad de Ciencias, Universidad de la República, Montevideo, Uruguay.

Levinsky, N.G. and Berliner, R.W. (1959) Changes in composition of the urine in ureter and bladder at low urine flow. American Journal of Physiology 196: 549-553.

Levinsky, N.G. and Levy, M. (1973) Clearances techniques. Pages 103-128 in Orloff, J. and Berliner, R.W. (Eds) Handbook of physiology. Section 8: Renal physiology. American Physiological Society, Washington.

Lowrance, P.B., Nickel, J.F., Smythe, C.M. and Bradley, S.E. (1956) Comparison of the effect of anoxic anoxia and apnea on the renal function in the harbor seal (Phoca vitulina). Journal of Cellular and Comparative Physiology 48: 35-49.

Murdaugh, H.V., Schmidt-Nielsen, B., Wood, J.W. and Mitchell, W.L. (1961) Cessation of renal function during diving in the trained seal (Phoca vitulina). Journal of Cellular and Comparative Physiology 58: 261-265.

Ortiz, C.L., Costa, D. and LeBoeuf, B.J. (1978) Water and energy flux in elephant seal pups fasting under natural conditions. Physiological Zoology 51(2): 166-178.
Páez, E. (1999) [Bootstrap and power analysis utilisation in abundance estimations of Arctocephalus australis pups] Utilización del Bootstrap y análisis de poder en estimaciones de abundancia de cachorros de Arctocephalus australis in Rey, M., Amestoy, F. and Arena, G. (Eds.) [Synopsis on the biology and ecology of South America fur seals and southern sea lions of Uruguay. Guidelines to their management and administration] Sinopsis de la biología y ecología de las poblaciones de lobos finos y leones marinos de Uruguay. Pautas para su manejo y administración. Instituto Nacional de Pesca (INAPE) Ministerio de Ganadería, Agricultura y Pesca (MGAP) Programa de las Naciones Unidas para el Desarrollo (PNUD) Technical Report INAPE-PNUD URU/ 92/003 Montevideo.

Page, L.B., Scott-Baker, J.C., Zak, A., Becker, E.L. and Baxter, C.F. (1954) The effect of variation in filtration rate on the urinary concentrating mechanism in the seal, Phoca vitulina L. Journal of Cellular and Comparative Physiology 43(3): 257-269.

Parker, K.L., DelGiudice, G.D. and Gillingham, M.P. (1993) Do urinary urea nitrogen and cortisol ratios of creatinine reflect body-fat reserves in black-tailed deer? Canadian Journal of Zoology 71: 1841-1848.

Pilson, M.E.Q. (1970) Water balance in california sea lions. Physiological Zoology 43: 257-269.

Ponce de León, A., Malek, A. and Pin, O. (1988) [Preliminary report on the diet of South America Fur Seal, Arctocephalus australis (Zimmermann, 1783) (MAMMALIA - OTARIIDAE) for 1987 - 1988 period] Resultados preliminares del estudio de la alimentación del Lobo Fino Sudamericano, Arctocephalus australis (Zimmermann, 1783) (MAMMALIA - OTARIIDAE), para 1987-1988. Page 14 in Abstracts, III Reunión de Trabajo de Especialistas en Mamíferos Acuáticos de América del Sur, July 25-30, Montevideo, Uruguay.

Sands, J.M. (1999) Regulation of renal urea transporters. Journal of the American Society of Nephrology 10: 635-646.

Schmidt-Nielsen, B., Murdaugh, H.V., O'Dell, R. and Bacsanyi, J. (1959) Urea excretion and diving in the seal (Phoca vitulina L.). Journal of Cellular and Comparative Physiology 53: 393-411. Schweigert, F. (1993a) Effects of fasting and lactation on blood chemistry and urine composition in the gray seal (Halichoerus grypus). Comparative Biochemistry and Physiology 105A(2): 353-357.

Schweigert, F. (1993b) Effects of energy mobilization during fasting and lactation on plasma metabolites in the Gray Seal (Halichoerus grypus). Comparative Biochemistry and Physiology 105A: 347-352.

Shannon, J.A. (1938) Urea excretion in the normal dog during forced diuresis. American Journal of Physiology 122: 782-787.

Siegel, S. (1956) Nonparametric statistics for the behavioral sciences. McGraw-Hill New York.

Smith, H.W. (1936) The composition of urine in the seal. Journal of Cellular and Comparative Physiology 7: 465-474.

Snedecor, G.W. and Cochran, W.G. (1980) Statistical methods. $7^{\text {th }}$. Ed. Iowa State University Press, Ames.

Tarasoff, F.J. and Toews, D.P. (1972) The osmotic and ionic regulatory capacities of the kidney of the harbor seal, Phoca vitulina. Journal of Comparative Physiology 81: 121-132.

Vaz-Ferreira, R. (1956) [Terrestrial ecology of Arctocephalus australis (Zimmermann) ("lobo fino") in Uruguayan islands] Ecología terrestre de Arctocephalus australis (Zimmermann) ("lobo fino") en las islas uruguayas. Servicio Oceanográfico y de Pesca. Trabajos Sobre Islas de Lobos y Lobos Marinos. Ministerio de Industrias y Trabajo, Montevideo, Uruguay. 2: 1-22.

Vaz-Ferreira, R. (1982) Arctocephalus australis Zimmermann, South American fur seal. Mammals in the seas. FAO Fish. Ser. 4(5): 497-508. 
Vaz-Ferreira, R. and Ponce de León, A. (1987) South American Fur Seal, Arctocephalus australis, in Uruguay in Croxall, J.P. and Gentry, R.L. (Eds) Status, biology and ecology of fur seals. Proceedings of an International Symposium and Workshop. Cambridge, England. 23-27 April 1984. NOAA Tech. Rep. NM FS 51:29-32.

Wallach, J.D. and Boever, W.J. (1983) Diseases of exotic animals: medical and surgical management. Saunders, Philadelphia.

Ximénez, I., Ponce de León, A., Batallés, M., Lima, M. and Malek, A. (1984) [Correlations between standard lenght, corporal weight, and weight of some viscera in
Arctocephalus australis] Grado de asociación entre la longitud, peso total y peso de algunos órganos en Arctocephalus australis. Anales ILPE (Montevideo). 1(4): 59-72.

Zimmermann, E.A.W. von (1783) [Geographic history of Man, and the widely distributed quadrupeds, with a corresponding zoological worldchart] Geographische Geshichte des Menschen, und der allgemein verbreiteten vierfüssigen Thiere, mit einer hiezu gehörigen Zoologischen Weltcharte. Vol.3 Weygandschen Buchhandlung, Leipzig. 